\title{
The Peculiarities of the Pedagogical Experiment Realization of Training Program in Forming Self Confidence among Senior Pupils
}

\author{
Glushko Larysa \\ ORCID https://orcid.org/0000-0002-9175-7935 \\ Interregional Academy of Personnel Management (Ukraine, Kyiv) \\ Ph.D., Associate Professor
}

\begin{abstract}
The article presents the formation of Self Confidence among senior secondary school pupils. Self Confidence is characterized as a complex of personality characteristic that includes emotional (fear and anxiety), behavioral (a lack of social skills) and cognitive components (clarity of thought, intellectual feelings) and the ability to make demands in the process of interaction in the social surroundings. The most significant factors that contribute to forming Self Confidence among senior pupils are outlined: the possibility of informal communication, providing emotional support, mutual assistance, communication among pupils "on an equal footing", a lack of classmates' pressure, acceptance of individuality of each, belonging to a social group. Self Confidence is characterized by personal attributes such as assertiveness, optimism, enthusiasm, affection, pride, independence, trust, the ability to handle criticism and emotional maturity.

Key words: Self Confidence, senior secondary school pupils, training program.
\end{abstract}

Актуальність дослідження. Зміна суспільних пріоритетів, модернізація національної системи освіти на засадах особистісно орієнтованого підходу об'єктивують необхідність посилення уваги до створення у навчальних закладах сприятливих умов для розвитку самостійної, творчої, життєздатної людини 3 розвиненою самоповагою. Вивчення проблеми впевненості людини у собі в останні десятиліття привертає науковців саме в аспекті зосередження

уваги на школяреві, формування у нього здатності до творчої самореалізації власного потенціалу, розвитку суб’єктності та впевненості в собі.

Проблему впевненості особистості досліджували Н. Будіч, В. Вендланд, В. Лабунська, М. Мішечкіна, С. Мєдвєдєва, В. Ромека, О. Рудик, В. Тернопільська, I. Толкунова, О. Хомчук, О. Шило та ін. [3; 5; 6; 9; 10; 16].

Виклад основного матеріалу. Впевненість у собі ми розуміємо як властивість особистості, ядром якої виступає позитивна оцінка індивідом особистісних навичок i 
здібностей достатніх для задоволення потреб та досягнення цілей за умови максимального використання власних сил та можливостей, формування позитивної оцінки власних навичок та здібностей, які визначають соціальну сміливість у визначенні нових завдань що відбуваються у формі впевненості в собі, високій самооцінці можливостей пізнання істини через прояв вольових якостей.

Формувальний етап нашого експерименту був спрямований на: 1) розвиток та сприйняття себе старшокласником як цілісної особистості; сприяння адекватному самооцінюванню, підкріплення позитивної «Я-концепції», оволодіння прийомами самопізнання; розвиток у школярів свідомого прийняття дійсності, переживання якої відбувається за принципом «тепер-та-зараз»; усвідомлення самого себе; 2) розвиток емоційного інтелекту, вміння адекватно виражати свої емоційні стани, в тому числі й негативні; керувати своїми емоціями загалом; 3) формування впевненості у собі; організація цілеспрямованого засвоєння навичок спілкування, вміння встановлювати нові соціальні контакти; формування умінь визначати позитивні життєві програми, приймати самостійно рішення, виконувати особливі стратегії взаємодії, спрямовані на поліпшення свого становища у соціумі; формування здатності до самоконтролю у різноманітних життєвих ситуаціях.

Одним із ефективних методів, який застосовувався у процесі роботи, був метод контакту та діалогу у процесі впливу. Зокрема будь-який тренінг буде ефективним у тому випадку, якщо в його структурі передбачено (проходить «наскрізною ниткою») процес самоаналізу і самодослідження особистості його учасників. Це один із стратегічних принципів, яким ми також керувалися, розробляючи програму для старшокласників. Необхідно відзначити, що, розвиваючи таку якість як впевненість у собі, необхідно створювати групову підтримку від оточуючих, які, підтримуючи партнерів по групі, через соціально-психологічні механізми ідентифікації, партнерського злиття і проективності, здатні перейти до вирішення емоційних проблем, що перешкоджають розвитку впевненості в собі. 3 іншого боку - активна робота в групі сприяє встановленню позитивних взаємин, що актуалізує установки старшокласників і, таким чином, вимагає негайного їх усвідомлення, що й потрібно для формування такої якості як впевненості в собі [15]. 
Групова робота із старшокласниками відрізняється тим, що ведучий, виконуючи роль фасилітатора й одночасно володіючи багатим, різноманітним за своєю специфікою арсеналом соціально-педагогічних засобів, активно стимулює учасників до ментальних (внутрішніх) і реальних (зовнішніх) дій та вчинків, які, закріплюючись у системі особистісних установок і цінностей, ведуть до вияву впевненості в собі [12].

Таким чином, завданням нашої тренінгової програми було вивільнення внутрішніх резервів задля розвитку відповідальності, самостійності, самоповаги особистості як важливих складових впевненої поведінки.

Передачу досвіду впевненості у собі надає педагог, який упроваджує активний діалог і обмін досвідом між юнаками і дівчатами. У цьому випадку ми активно застосовували монолог педагога на певну тему (вербалізація досвіду), полілог (відповіді педагога на запитання групи) і діалог. Метою заняття-тренінгу «У пошуках власного «Я» $є$ сприяння психічному й особистісному зростанню старшокласників; розвиток у них навичок самопізнання, самоаналізу, які впливають на становлення «Яконцепції», самоповаги; уміння критично оцінювати себе та інших, розуміти свої бажання та можливості; формування позитивних рис особистості.

Метою заняття-тренінгу «У пошуках власного «Я» $є$ сприяння психічному й особистісному зростанню старшокласників, розвиток у них навичок самопізнання, самоаналізу, які впливають на становлення «Я-концепції», самоповаги; уміння критично оцінювати себе та інших, розуміти свої бажання та можливості; формування позитивних рис особистості.

Поняття для засвоєння: самоаналіз, самопізнання, саморозвиток, самоефективність, особистісний розвиток, критичне мислення, «Я-концепція», самоповага.

Учні будуть знати: як, спираючись на свої позитивні якості й риси характеру, використовувати отримані в результаті діагностики та самоаналізу дані для побудови власної життєвої позиції.

Старшокласники будуть уміти: компетентно оцінювати свої можливості, якості особистості, поведінку; формувати позитивну «Я-концепцію» та достатній рівень самоповаги.

Матеріали: 2 аркуші ватману («Мішок очікувань» і «Правила групи»). 
Роздатковий матеріал: фліп-чарт, маркери різних кольорів; два легких м'ячі різного кольору; картки для самодіагностики, плакат «Я - багатогранне».

Класну кімнату рекомендуємо оформити висловами видатних людей про пізнання себе.

\section{Хід заняття}

Вступне слово. Кожен із нас постійно вживає займенник «Я». Я працюю, думаю, приймаю рішення. Але хто такий цей «Я», як він виглядає, як поводиться, як може діяти в тій чи іншій ситуації, наскільки він розумний? Це «Я» живе в людині у вигляді уявлення про себе. «Я» - це те, ким людина вважає себе в думках, почуттях і діях. На занятті ми спробуємо прокласти шлях до власного «Я»: «Я - це мої вчинки». Реальні вчинки не обманюють, як це робить розум, і вони не настільки розпливчасті, як почуття й емоції. Кожен вчинок, кожна реальна дія в реальному світі - це факт, це тверде i абсолютно однозначне вираження сутності людини.

Хочете пізнати себе - вивчайте свої вчинки.

Вирава «Оцініть свої знання про себе».

Ведучий. Перевірте, наскільки добре ви знаєте себе (табл. 1), а також оцініть свої

Таблиия 1

\section{Оцінка знань про себе}

\begin{tabular}{|l|l|l|l|}
\hline № & \multicolumn{1}{|c|}{ Твердження } & 3+2+10-1-2-3 & \multicolumn{1}{|c|}{ Твердження } \\
\hline 1 & Я вивчаю свої можливості & & Я не вивчаю своїх можливостей \\
\hline 2 & Я знаю риси свого характеру & & Я не знаю рис свого характеру \\
\hline 3 & Я знаю своїх фізичні дані & Я не знаю своїх фізичних даних \\
\hline 4 & Я знаю свій тип темпераменту & Я не знаю свій тип темпераменту \\
\hline 5 & $\begin{array}{l}\text { Я можу впоратися зі своїми } \\
\text { емоціями }\end{array}$ & $\begin{array}{l}\text { Я не можу впоратися зі своїми } \\
\text { емоціями }\end{array}$ \\
\hline 6 & $\begin{array}{l}\text { Я хочу пізнавати себе, свої } \\
\text { можливості }\end{array}$ & $\begin{array}{l}\text { Я не хочу пізнавати себе, свої } \\
\text { можливості }\end{array}$ \\
\hline
\end{tabular}

знання за принципом диференціалу: твердження, розташовані зліва, оцініть у діапазоні від +3 до +1; твердження, розташовані справа, - у діапазоні від -1 до -3.

Якщо ви поставили оцінку ліворуч, то праворуч ставити іï не треба, i, навпаки, проставлена справа оцінка передбачає відсутність оцінки твердження, розташованого 
зліва. Підрахуйте кількість балів, підсумовуючи «+» i, якщо більше у вас буде «+», то краще ви себе знаєте.

Пропонуємо такі запитання для обговорення: Що нового ви дізналися про себе? Що дала вам ця вправа? Який висновок можна зробити?

Інформаційне повідомлення. Усе, що ви знаєте й уявляєте про себе, називається вашим образом «Я». Він багатогранний, по-різному проявляється в різноманітних ситуаціях: ви можете на уроці бути тихим і скромним учнем, вдома - «бурею», у колі ровесників - хорошим товаришем тощо.

Одне «Я» у вас зовнішнє (фізичне), а є ще «Я» внутрішнє (психічне). С «Я» усвідомлюване (ви можете його описати словами, наприклад: «Я - високий, красивий»), є «Я» неусвідомлюване (ви не знаєте, чому так ставитеся до чого-небудь, наприклад, чому ви любите запах троянди). $Є$ «Я», що думає про себе й відчуває себе, свій внутрішній світ, і є «Я», що поводиться певним чином («Я - поведінкове»). У людині майже завжди співіснують і позитивні, і негативні якості: «Я»-хороше, добре і «Я»- погане, зле. Ви пам'ятаєте себе в минулому, відчуваєте в майбутньому. Інколи уявляєте нереальні, фантастичні образи себе, у вас $є$ ідеал «Я», яким ви хотіли б стати.

Отже, ваш складний, багатогранний образ «Я» такий (демонструється плакат «Я»- багатогранне»), а саме:

- Я - багатогранне рольове (у різних ролях);

- внутрішне/зовнішне;

- усвідомлюване/неусвідомлюване;

- поведінкове; хороше/погане;

- минуле/теперішнє/майбутнє;

- фантастичне;

- ідеальне/реальне.

Прийом спілкування «Я» - «Ти», який використовувався нами у тренінгу, відрізнявся тим, що створювалася унікальна атмосфера зближення та взаємного проникнення двох особистостей - суб'єктивних реальностей.

Наводимо план бесіди дискусії «Чи знаємо ми себе?»:

1) зміст понять «людина», «індивід», «особистість», «індивідуальність»;

2) самооцінка як центральне особистісне утворення та компонент «Я концепції» [13]. 
Презентуємо вправу «Займи позицію».

1. Звернімось до слів Дугласа Макартура, який говорив, що «у цьому світі немає гарантій, є тільки можливості». (Плакат на дошці). Дайте відповідь на запитання: «Чи легко в сучасному світі реалізувати свої можливості?» Якщо так, станьте у класі біля плаката із написом «Так», далі, відповідно, біля плакатів «Ні», «Не знаю», «Для мене це складне запитання».

2. Підготовка учнів до обгрунтування своєї позиції, чому саме вони ії обрали, та пояснення представниками кожної групи з наведенням аргументу. (Один учень - один аргумент).

3. Вислуховування позицій та аргументів інших. (Варіанти учнівських відповідей: «Так, в сучасному світі легко реалізувати свої можливості, адже для цього є багато засобів. Головне - мати бажання їх знайти». «В сучасному світі важко реалізувати свої можливості, адже не кожен знаходить ці засоби»).

4. Якщо після обговорення цього питання хтось із учнів змінить свою позицію, треба йому запропонувати стати біля відповідного плаката та пояснити, чому змінилась його думка. (Учні, що знаходяться біля плаката «ТАК», повинні переконати інших учнів зайняти їх позицію).

5. Рефлексія. Чим сподобалась ця вправа? Що для себе ви з’ясували?

Метою вправи «Як обрати вірну мету та ї̈ досягти?» є формування уміння реалістичної постановки особистісно значущих цілей та покроковому аналізі засобів їх досягнення.

Метою вправи «Алгоритм картини майбутнього» $є$ спрямувати смислову пошукову активність старшокласників на визначення власних цілей, розвинути уміння розробляти програму конкретних етапів віддаленої мети, яка має велике значення для особистості.

Інструкція. Ведучий вносить пропозицію учасникам експериментального класу занотувати наступне:

1. Визначте свою освітню мету на 5 найближчих років.

2. Чітко уявіть собі картину майбутнього.

3. Ким ви станете через 5 років?

4. Яку отримаєте освіту? 
5. Як ви будете себе відчувати?

6. Якими стануть ваші перспективи на майбутнє?

Визначте поетапно, що ви повинні зробити впродовж кожного із цих 5 років, щоб досягти мети? Сформулюйте свій девіз на найближчі 3 місяці. Через три місяці складіть новий девіз, а потім повторюйте його. Коригуйте, уточнюйте, конкретизуйте цей девіз кожні три місяці.

Обговорення. Аналізуються змістовність визначених цілей, наявність близьких цілей, продуманість етапів їх реалізації [8].

Вправа «Самооцінка». Метою вправи «Самооцінка» $\epsilon$ формування у старшокласників поняття про самооцінку та пї види; формуванню адекватної самоццінки; визначення взаємозв'язку самооцінки та самоповаги.

Методи: традиційні, нетрадиційні.

Засоби: схеми; використання інтерактивної дошки.

Методики: опитувальник «Шкала самоповаги Розенберга», дослідження самооцінки за методом Дембо - Рубінштейн (модифікація А. Прихожан).

Організація класу до роботи $(0,5$ хв.).

Сьогодні ми поговоримо про ставлення до самого себе - самооцінку. Як ви думаєте, чому так важливо пізнати самого себе?

Учні висловлюють свої думки.

Дійсно, не знаючи себе, не отримавши відповіді на питання «Що я хочу?» практично неможливо будувати плани на майбутне, взаємодіяти з іншими людьми. Так складається, що ми постійно оцінюємо себе і свої можливості, порівнюємо себе 3 оточуючими і в результаті отримуємо стійкий набір про свій інтелект, зовнішність, здоров'я, стан у суспільстві.

Самооцінка складається зі знання про себе самого та ставлення до самого себе. Учитель записує на дошці:

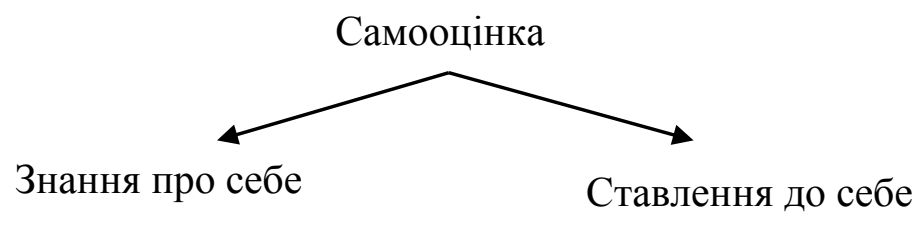


Учні записують у зошити за вчителем. Самооцінка може бути як адекватною, тобто відповідати дійсним якостям, нахилам і здібностям людини, так і неадекватною завищеною або заниженою. Часто говорять про високу і низьку самооцінку, адекватну і неадекватну, при цьому необхідно пам'ятати, що і висока, і низька самооцінка можуть бути і адекватною, і неадекватною. Частково розібрались у видах самооцінки і тепер давайте занотуємо, що самооцінка може бути адекватною, тобто відповідати дійсним якостям і здібностям людини і неадекватною - завищеною або заниженою.

Висновки. Отже реалізація тренінгової програми сприяла формуванню у досліджуваних учнів здатності впевнено, активно включатись у діяльність, оптимізуючи індивідуальний свідомий вибір та відкритість у стосунках, інтернальність як орієнтацію на власні сили й можливості.

\section{References}

1. Golovatiy M.F. Navchi sebe sam: [navch. metod, rozrobka]. Kyiv: MAUP, 2002. $120 \mathrm{p}$.

2. Dyatlenko N.M. Samopovaha ditei [Self-esteem of children]. Kyiv: Shk.svit, 2007. P. 55-56.

3. Kanishevska L.V. The research of the issue of educating social maturity in senior students of boarding schools. Pedagogical almanac: a compilation of research works. Kherson KHEE "Khersonska academy of continuous education", 2012. Issue 16. P. 213-220.

4. Kirsanov V.V. Psykholoho-pedahohichna diahnostyka [Psychologicalpedagogical diagnostics]: pidruchnyk. Kyiv: AlterPres, 2002.

5. Pet ko L.V., Verezij V.F. Pidlitok u riznovikovomu zagoni [Teenager in different age group] // Rad. shkola. Kyiv. 1989. No. 11. P. 6-12.

6. Pet'ko L.V. Psyhologo-pedagogichna sutnist' social'no-komunikatyvnoi' aktyvnosti osobystosti [Psycho-pedagogical point of social and communicative activity of the personality]. Pedagogika vyshhoi' ta serednoi shkoly: zb.nauk. prac; gol. red. V.K.Burjak. Kryvyj Rig: KDPU, 2006. Issue. 15. P. 315-328.

7. Pet'ko L.V. Stymuliuvannia tvorchykh zdibnostei pidlitkiv zasobamy vtilennia obrazu kazkovoho personazhu [Stimulating of teens'creativity abilities in view of embodiment the image fairy-tale character's]. Lialka yak znak, obraz, funktsiia: Mater. vseukr. nauk.-prakt. konf. «Druhi Marka Hrushevskoho chytannia» / za red. O.S.Naidena. Kyiv: VD «Stylos», 2010. P. 200-204.

8. Tatenko V.A. Psykholohyia v subektyvnom izmerenii [Psychology in the Subjective Dimension]: monograph. Kyiv: Prosvita, 1996. 404 p. 
9. Ternopilska V.I. Vid samopiznannia do sotsialnoi vidpovidalnosti [From selfknowledge to social responsibility]: [navch. posibnyk]. Zhytomyr: Polihrafichnyi tsentr ZhDPU, 2003. 184 p.

10. Ternopilska V.I. Ideia vidpovidalnosti osobystosti $v$ humanitarnykh naukakh [The idea of personality's responsibility in the humanities]: Visnyk Zhytomyrskoho derzhavnoho un-tu imeni Ivana Franka. 2002. No. 9. P. 69-72.

11. Ternopilska V.I. Psykholohiia dlia starshoklasnykiv: sotsialno-komunikatyvnyi aspekt [Psychology for senior pupils: social and communicative aspect]: navch. posibnyk. Zhytomyr: Vyd-vo ZhDU im. I.Franka, 2009.

12. Treninhova robota z pidlitkamy [Training work with teenagers] / ukl. Vozianova O.A., Babenko K.M. Kyiv: Editorial board general pod. newspapers, 2012. 128 p.

13. Formuvannia sotsialnoi kompetentsii starshoklasnyka [Formation of social competence of senior pupils] / ukl. J. M. Stashko. Kyiv, 2011. 128 p.

14. Khomenko Z.I. Vplyv uchytelia na emotsiinyi stan uchniv [The Teacher's Influence on the Emotional Condition of Students]. Kyiv: Editorial board general. Newspapers. 2012. 128 p.

15. Hlushko L., Ternopilska V. Self-confidence: theoretical analysis. Problems of the development of mofern science: theory and practice:Collection of scientific articles. - EDEX, Madrid, Espaca, 2018. P. 189-193.

16. Ternopilska V.I. The role of self-government in development of leadership qualities among students. Problems of development modern science: theory and practice: Collection of scientific articles. - EDEX, Madrid, España, 2016. P. 327-330.

\section{Translation of the Title, Abstract and References to the Author's Language}

\section{УДК 316.614.6}

Глушко Лариса. Особливості педагогічного експерименту щодо реалізації тренінгової програми формування впевненості в собі у старшокласників.

У статті представлено формування впевненості у собі серед старшокласників. Охарактеризовано впевненість у собі як комплексну характеристику особистості, що включає емоційні (страх і тривожність), поведінкові (дефіцит навичок соціальної поведінки) і когнітивні компоненти (ясність і чіткість думок, інтелектуальні почуття) та здатність висувати вимоги у взаємодії із соціальним оточенням. Окреслено найбільш значимі чинники, що слугують формуванню впевненості у собі старшокласників: можливість неформального спілкування, надання емоційної підтримки, взаємодопомога, спілкування «на рівних», довіра, відсутність будь-якого тиску з боку однокласників, прийняття індивідуальності кожного, приналежність до групи.

Ключові слова: розвиток впевненості в собі, старшокласники, навчальна програма.

\section{Jimepamypa}

1. Головатий М. Ф. Навчи себе сам: [навч. метод, розробка]. Київ: МАУП, 2002. $120 \mathrm{c}$. 
2. Дятленко Н. М. Самоповага дітей. Київ: Шк.світ, 2007. С. 55-56.

3. Канішевська Л. В. Дослідження проблеми виховання соціальної зрілості старшокласників шкіл-інтернатів. Педагогічний альманах : зб. наук. праць. Херсон КВНЗ “Херсонська академія неперервної освіти”, 2012. Вип. 16. С. 213-220.

4. Кірсанов В. В. Психолого-педагогічна діагностика: підручник. Київ: Альтерпрес, 2002.

5. Петько Л. В. Підліток у різновіковому загоні / Л. В. Петько, В. Ф. Верезій. Рад. школа. Київ. 1989. № 11. С. 6-12.

URI http://enpuir.npu.edu.ua/handle/123456789/7865

6. Петько Л. В. Психолого-педагогічна сутність соціально-комунікативної активності особистості. Педагогіка вищої та середньої школи: зб.наук. пр. ; гол. ред. В.К.Буряк. Кривий Ріг: КДПУ, 2006. Вип. 15. С. 315-328.

7. Петько Л. В. Стимулювання творчих здібностей підлітків засобами втілення образу казкового персонажу // Лялька як знак, образ, функція: матер. всеукр. наук.практ. конф. «Другі Марка Грушевського читання» / за ред. О.С.Найдена. Київ: ВД «Стилос», 2010. С. 200-204.

8. Татенко В. А. Психология в субъективном измерении: монография. Київ: Просвита, 1996. 404 с.

9. Тернопільська В. І. Від самопізнання до соціальної відповідальності. [навч. посібник] ; за ред. проф. М. В. Левківського. Житомир: Поліграфічний центр ЖДПУ, 2003. $184 \mathrm{c}$.

10. Тернопільська В. I. Ідея відповідальності особистості в гуманітарних науках. Вісник Житомирського державного університету імені Івана Франка. 2002. № 9. C. 69-72.

11. Тернопільська В. I. Психологія для старшокласників: соціальнокомунікативний аспект: навч. посібник. Житомир: Вид-во ЖДУ ім. І.Я.Франка, 2009.

12. Тренінгова робота $з$ підлітками / упорядн. Возіянова О. А., Бабенко К. М. Київ: Ред. загальнопед. газет, 2012. 128 с.

13. Формування соціальної компетенції старшокласника / упоряд. Ж. М. Сташко. Київ, 2011. 128 с.

14. Хоменко 3. І. Вплив учителя на емоційний стан учнів. Київ: Редакція загальнопед. газет, 2012. 128 c.

15. Hlushko L., Ternopilska V. Self-confidence: theoretical analysis. Problems of the development of mofern science: theory and practice: Collection of scientific articles. EDEX, Madrid, Espaca, 2018. P. 189-193.

16. Ternopilska V.I. The role of self-government in development of leadership qualities among students. Problems of development modern science: theory and practice: Collection of scientific articles. - EDEX, Madrid, España, 2016. P. 327-330. 